\title{
KARAKTERISASI FITOPLASMA PENYEBAB PENYAKIT LAYU KELAPA DI PULAU DERAWAN MENGGUNAKAN RFLP IN SILICO
}

\author{
Agus Eko Prasetyo ${ }^{1}$, Kikin Hamzah Mutaqin ${ }^{2}, \&$ Giyanto ${ }^{2}$ \\ ${ }^{1}$ Pusat Penelitian Kelapa Sawit \\ Jl. Brigjend Katamso No 51 Medan 20158 \\ ${ }^{2}$ Departemen Proteksi Tanaman, Fakultas Pertanian, Institut Pertanian Bogor \\ Jl. Kamper Kampus IPB Dramaga, Bogor 16680 \\ E-mail: prasetyo_marihat@yahoo.com
}

\begin{abstract}
Characterization of phytoplasmas associated with coconut wilt disease in Derawan Island using in silico RFLP. Coconut wilt disease has been reported in Derawan Island that resulted in eradication up to $10 \%$ of the total cultivated palms. The objective of this study was to detect and characterize phytoplasmas associated with coconut wilt disease in Derawan island using nested PCR technique and in silico RFLP based on 16S rRNA gene sequences. Detection of phytoplasmas was performed using nested PCR method, cloning of nPCR products, sequencing, and analysis of sequencing results using in silico RFLP. The results revealed that phytoplasmas could not be detected by PCR using P1/P7 primer pairs however it could be amplified by nested PCR using R16F2n/R16R2 primer pairs resulting amplicon at about $1.25 \mathrm{~kb}$. In silico RFLP analysis indicated that phytoplasmas associated with coconut wilt disease in Derawan Island belong to 16SrII (witches broom phytoplasma). PCR product of the nPCR need to be sequenced because the R16F2n/R16R2 primer will also amplify the other bacterial species, mainly from Gram positive bacteria.
\end{abstract}

Key words: coconut wilt disease, phytoplasmas, nested PCR, sequencing

\begin{abstract}
ABSTRAK
Karakterisasi fitoplasma penyebab penyakit layu kelapa di Pulau Derawan menggunakan RFLP in silico. Penyakit layu kelapa telah ditemukan di Pulau Derawan, Kalimantan Timur yang mengakibatkan 10\% tanaman dieradikasi. Penelitian ini bertujuan untuk mendeteksi dan mengkarakterisasi fitoplasma yang berasosiasi dengan penyakit layu kelapa di Pulau Derawan. Kegiatan penelitian meliputi pengambilan sampel, ekstraksi DNA, deteksi fitoplasma menggunakan teknik nested-PCR(nPCR), kloning dan sekuensing, serta analisis hasil sekuensing menggunakan RFLP in silico. Hasil penelitian menunjukkan bahwa fitoplasma tidak terdeteksi menggunakan PCR dengan primer P1/P7 tetapi menjadi terdeteksi dengan nPCR menggunakan primer R16F2n/R16R2 yang memiliki amplikon DNA sekitar 1,25 kb. Hasil analisis sekuensing menggunakan RFLP in silico membuktikan bahwa fitoplasma yang berasosiasi dengan penyakit layu kelapa di Pulau Derawan tergolong ke dalam kelompok 16SrII (witches broom phytoplasma). Deteksi fitoplasma memerlukan sekuensing karena primer R16F2n/R16R2 masih dapat mengamplifikasi beberapa bakteri Gram Positif.
\end{abstract}

Kata kunci: penyakit layu kelapa, fitoplasma, nested-PCR, sekuensing

\section{PENDAHULUAN}

Keberadaan tanaman kelapa di Pulau Derawan, Kalimantan Timur, Indonesia mulai berkurang akibat adanya penyakit layu kelapa. Padahal, tanaman ini menjadi satu-satunya tanaman perkebunan yang dibudidayakan. Selain sebagai sumber pendapatan tambahan, tanaman kelapa di pulau ini juga memiliki fungsi estetika yakni menambah kecantikan pandang pantai di pulau yang menjadi maskot pariwisata di provinsi ini. Terlebih lagi, tanaman kelapa di Indonesia menjadi komoditi sosial kedua setelah padi dengan luas areal sekitar 3,7 juta ha atau setara dengan sepertiga luas kelapa dunia yang menjadikan Indonesia sebagai negara produsen kelapa terluas di dunia (Anonim, 2007). Kejadian penyakit layu terlihat cukup tinggi, tanaman 
mati hingga mencapai $10 \%$ sedangkan tanaman lain yang masih bergejala dapat menurunkan produksi buah.

Gejala penyakit layu kelapa di Pulau Derawan ditandai dengan menguningnya daun, pelepah-pelepah maupun daun kelapa yang muncul terlihat lebih pendek daripada tanaman kelapa yang normal (sehat), mengeringnya daun (klorosis) yang dimulai dari bagian daun yang tua (bawah), pangkal pelepah tua mudah patah, terjadinya pengguguran buah kelapa yang masih muda atau jika masih ada buah kelapa yang tersisa sampai besar dan masak, biasanya hanya 1 atau 2 biji saja. Gejala akhir penyakit ini adalah mengeringnya seluruh pelepah dan daun kelapa rontok dan terlihat hanya seperti tonggak batang kayu. Menurut Leon et al. (1996), tanaman yang sakit akan menghasilkan asam absisat dan etilen yang sangat tinggi. Akibatnya terjadi ketidak-seimbangan hormon yang akan memacu penuaan daun dan mengakibatkan patahnya pelepah serta gugurnya buah yang masih muda (Musetti, 2010).

Sebelumnya, di daerah Sampit, Kalimantan Tengah ditemukan penyakit layu Kalimantan (kalimantan wilt) yang kemudian berhasil diidentifikasi oleh Warokka et al. (2006) disebabkan oleh ca. Phytoplasma oryzae (Warokka et al., 2006). Di Malaysia, ditemukan ca. Phytoplasma cynodontis yang menjadi penyebab penyakit coconut lethal decline (Nejat et al., 2009). Strain fitoplasma yang telah diketahui menyebabkan kerugian yang sangat besar pada tanaman kelapa di daerah Amerika dan Afrika adalah ca. Phytoplasma palmae, penyebab penyakit lethal yellowing (Tymon et al., 1998; Harrison et al., 2002; Myrie et al., 2006). Strain fitoplasma terakhir masuk dalam kelas A1 Karantina Tumbuhan Indonesia karena selain tanaman kelapa, strain ini juga diduga dapat menyerang tanaman kelapa sawit yang saat ini menjadi sumber devisa non migas utama di Indonesia. Menurut Weintraub \& Wilson (2010), sampai saat ini, pengendalian patogen ini pada tanaman kelapa belum ada yang memuaskan.

Deteksi dan karakterisasi fitoplasma sebagai penyebab penyakit layu kelapa di Pulau Derawan sangat penting dilakukan untuk mencegah terjadinya ledakan penyakit. Penelitian ini bertujuan untuk mengidentifikasi dan mengklasifikasikan fitoplasma yang berasosiasi dengan penyakit layu kelapa di Pulau Derawan berdasarkan sekuen gen 16S rRNA menggunakan metode Restriction Fragment Length Polymorphism (RFLP) in silico. Penelitian ini sangat bermanfaat sebagai langkah awal dalam menyusun strategi pengendalian penyakit.

\section{METODE PENELITIAN}

Tempat dan Waktu. Pengambilan sampel dilakukan di Pulau Derawan, Kalimantan Timur kemudian dilanjutkan dengan ekstraksi DNA di Laboratorium Bakteriologi, Departemen Proteksi Tanaman, Fakultas Pertanian, Institut Pertanian Bogor. Proses PCR maupun nestedPCR, kloning dan sekuensing dilakukan di Laboratorium Genomic of Bacterial Cell Function, Nara Institute of Science and Technology (NAIST) Jepang. Analisis RFLP in silico dilakukan di Divisi Proteksi Tanaman, Pusat Penelitian Kelapa Sawit, Medan. Penelitian ini dilakukan pada September 2011 hingga September 2013.

Pengambilan Sampel. Pengambilan sampel dilakukan di Pulau Derawan, Kalimantan Timur. Sampel batang tanaman kelapa dibor menggunakan bor kayu berdiameter $1 \mathrm{~cm}$ pada ketinggian sekitar 1 meter dari permukaan tanah sedalam 15-20 cm (Oropeza et al., 2002). Kriteria tanaman sampel adalah tanaman dengan gejala penyakit ringan (daun menguning dan mulai klorosis), berat (daun klorosis, mengering dan tidak memproduksi buah), dan tanaman yang tidak bergejala penyakit masing-masing 6 tanaman dengan 3 sisi pengeboran yang berbeda. Sebagai kontrol positif digunakan sampel tanaman kelapa terserang penyakit layu Kalimantan dari daerah Sampit dan beberapa sampel tanaman kacang tanah dan kedelai yang terserang penyakit sapu setan dari daerah Bogor.

Ekstraksi DNA dan Amplifikasi menggunakan PCR. DNA fitoplasma dari serbuk kayu kelapa diekstraksi menggunakan metode Zhang et al. (1998). DNA hasil ekstraksi diamplifikasi berturut-turut menggunakan dua pasang primer universal fitoplasma, P1 (5'-AAG AGT TTG ATC CTG GCT CAG GAT T3') (Deng \& Hiruki 1991) / P7 (5'-CGT CCT TCA TCG GCT CTT-3') dan dilanjutkan dengan pasangan primer R16F2n (5'-GAA ACG ACT GCT AAG ACT GG-3') / R16R2 (5'-TGA CGG GCG GTG TGT ACA AAC CCC G-3') (Gundersen \& Lee, 1996). Reaksi PCR dilakukan pada volume $10 \mathrm{ml}$ yang terdiri dari $1 \mathrm{ml}$ template DNA, $1 \mathrm{ml}$ dNTPs $(2 \mathrm{mM}) ; 0,6 \mathrm{ml} \mathrm{MgSO}_{4}$ $(25 \mathrm{mM}) ; 1 \mathrm{ml}$ primer forward (2 pmol); $1 \mathrm{ml}$ primer reverse (2 pmol); 0,1 ml Taq KOD plus Neo; dan 4,3

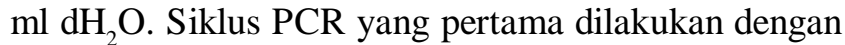
menggunakan pasangan primer $\mathrm{P} 1 / \mathrm{P} 7$ dimulai dengan satu siklus pemanasan awal pada suhu $94{ }^{\circ} \mathrm{C}$ selama 2 menit; dilanjutkan dengan 35 siklus yang terdiri dari 
denaturasi dengan suhu $94{ }^{\circ} \mathrm{C}$ selama 15 detik, penempelan primer dengan suhu $54{ }^{\circ} \mathrm{C}$ selama 30 detik, ekstensi dengan suhu $68{ }^{\circ} \mathrm{C}$ selama 1 menit 30 detik. Sebanyak $1 \mathrm{ml}$ hasil PCR pertama ini digunakan sebagai -template (cetakan) untuk PCR kedua dengan pasangan primer R16F2n/R16R2. Siklus pemanasan PCR kedua sama dengan PCR yang pertama, hanya berbeda pada suhu penempelan primer yakni $57^{\circ} \mathrm{C}$.

Kloning Produk Nested PCR. Terdapat empat tahapan kloning, meliputi preparasi sel bakteri kompeten, insersi produk nPCR ke dalam DNA plasmid, transformasi DNA plasmid ke sel bakteri kompeten, dan isolasi plasmid. Sel bakteri yang digunakan sebagai sel kompeten adalah Eschericia coli DH5a dengan metode metode Inoue "ultra competent" cells (Sambrook \& Russel, 2001). Produk nPCR diinsersikan ke dalam plasmid pDONR ${ }^{\mathrm{TM}} 201$ (Invitrogen) dengan sistem gateway. Plasmid yang telah mengandung produk $\mathrm{nPCR}$ kemudian ditransformasikan ke sel bakteri kompeten DH5 $\alpha$ dengan metode heat shock (Sambrook \& Russell, 2001) dengan seleksi bakteri dilakukan pada media LB + kanamycin $50 \mu \mathrm{g} / \mathrm{ml}$. Tahap akhir yaitu isolasi plasmid dilakukan dengan metode alkalin lisis dengan SDS (Sambrook \& Russell, 2001).

Sekuensing. DNA plasmid yang digunakan sebagai template, sebelumnya telah diencerkan 100-200 kali. Reaksi PCR dilakukan dengan komposisi $1 \mathrm{ml} 5 \mathrm{X}$ bufer sekuensing; $0,5 \mathrm{ml}$ primer $\mathrm{F}$ atau $\mathrm{R}$ (2 pmol); $2 \mathrm{ml}$ DNA plasmid; $1 \mathrm{ml}$ big dye; dan 0,5 $\mathrm{ml} \mathrm{d}_{2} \mathrm{O}$. Mesin PCR diatur dengan satu siklus denaturasi awal dengan suhu
$94{ }^{\circ} \mathrm{C}$ selama 2 menit; dilanjutkan dengan 25 siklus yang terdiri dari denaturasi dengan suhu $96^{\circ} \mathrm{C}$ selama 10 detik, penempelan primer dengan suhu $50{ }^{\circ} \mathrm{C}$ selama 5 detik, ekstensi dengan suhu $60^{\circ} \mathrm{C}$ selama 3 menit. Proses sekuensing dilakukan pada mesin sekuenser $\mathrm{ABI}$ PRISM 3100 Genetic Analyzer (Applied Biosystem).

\section{Pemotongan Fragmen DNA dengan Enzim} Restriksi secara In Silico. Sekuen DNA hasil sekuensing dimasukkan pada program pDRAW32 yang dikembangkan oleh AcaClone Software (http:// www.acaclone.com). Masing-masing sekuen DNA kemudian dipotong-potong menggunakan 17 macam enzim restriksi yang baku digunakan untuk analisis RFLP gen 16S rRNA fitoplasma (Wei et al., 2007). Enzimenzim restriksi tersebut adalah $A l u \mathrm{I}, B a m \mathrm{HI}, B f a \mathrm{I}, B s t \mathrm{UI}$ (ThaI), DraI, EcoRI, HaeIII, HhaI, HinfI, HpaI, HpaII, KpnI, Sau3AI (MboI), MseI, RsaI, SspI, dan TaqI. Setelah dipotong, kemudian diplotkan dengan elektroforesis gel agarose 3\%.

\section{HASIL DAN PEMBAHASAN}

Deteksi Fitoplasma dengan Nested-PCR. Hasil amplifikasi DNA menggunakan primer universal P1/P7 hanya menghasilkan amplikon DNA fitoplasma yang berasal dari kacang tanah dan kedelai pada gel agarose, yang digunakan sebagai kontrol positif. Produk amplifikasi yang dihasilkan adalah sekitar $1,8 \mathrm{~kb}$ (Gambar 1) yang di dalamnya terkandung gen yang dekat dengan awal 16S rRNA, daerah interspacer (ITS), dan bagian ujung 5' gen 23S rRNA. Namun,

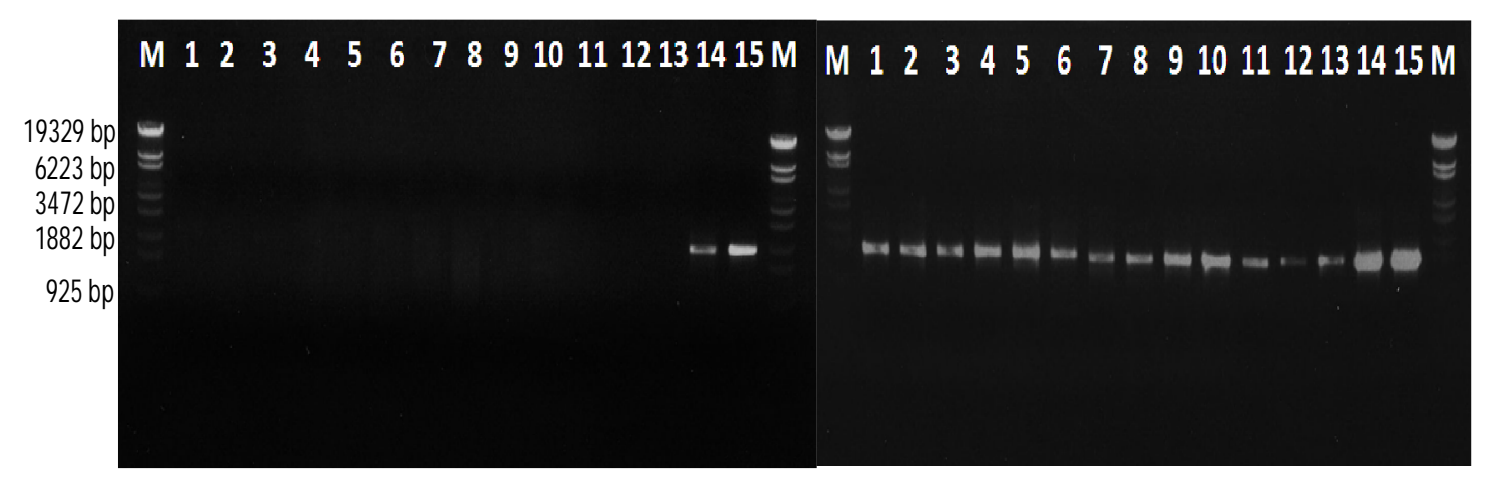

Gambar 1. Amplifikasi sampel yang diduga terinfeksi fitoplasma menggunakan primer P1/P7 (kiri) dan R16F2n/ R16R2 (kanan). Lajur M, 1 Eco T14I digest ladder; 1-2, sampel kelapa belum bergejala dari Pulau Derawan; 3-6, sampel kelapa bergejala ringan dari Pulau Derawan; 7-10, sampel kelapa bergejala berat dari Pulau Derawan; 11-13, sampel kelapa dari Sampit; 14, sampel kedelai; 15, sampel kacang tanah. 
nPCR dari hasil amplikon PCR pertama memperlihatkan adanya fragmen DNA dari sampel kelapa yang berukuran sekitar $1,25 \mathrm{~kb}$ yang mengandung internal gen 16S rRNA (Gundersen \& Lee, 1996).

Semua sampel dari tanaman kelapa bergejala layu ringan dan berat (masing-masing 6 tanaman) dari Pulau Derawan menunjukkan hasil positif dengan nPCR, sedangkan pada tanaman yang belum bergejala hanya 3 tanaman yang positif (sebagian ditunjukkan pada Gambar 1). Setelah disekuensing dan dilakukan uji BLAST dari NCBI, diperoleh bahwa 77,78\% (dari total 15 tanaman bergejala berat, ringan dan belum bergejala) sekuen DNA produk nPCR sangat mirip dengan beberapa strain fitoplasma dan $23,22 \%$ bukan merupakan fitoplasma. Terdeteksinya fitoplasma pada tanaman kelapa yang belum bergejala menunjukkan bahwa patogen tersebut telah menginfeksi tanaman namun belum menimbulkan gejala penyakit. Hal ini membuktikan bahwa metode nPCR dapat digunakan untuk mendeteksi fitoplasma pada tanaman yang sakit maupun sehat secara visual. Meskipun demikian, identifikasi fitoplasma memerlukan sekuensing karena terdeteksinya sekuen DNA bukan fitoplasma dengan ukuran yang sama sekitar $1,25 \mathrm{~kb}$ baik pada tanaman sakit maupun sehat.

Sekuen DNA yang mirip dengan spesies bukan fitoplasma meliputi Bacillus megaterium, Bacillus sp., Clostridium sp., Friedmaniella lacustris, dan
Lagionella birminghamensis memiliki nilai homologi 93-96\%, yang termasuk ke dalam bakteri Gram Positif. Menurut Bai et al. (2006), fitoplasma erat berhubungan dengan bakteri Gram Positif khususnya grup Bacillus dan Clostridium. Hal ini berarti banyak sekuen gen fitoplasma dan bakteri Gram Positif yang akan memiliki kesamaan. Terdeteksinya berbagai strain bakteri Gram Positif ini juga mengindikasikan bahwa primer fitoplasma yang digunakan belum spesifik.

Hasil uji RFLP in silico dari sampel asal Pulau Derawan menunjukkan adanya 6 pola potongan fragmen DNA yang berbeda (Gambar 2). Keenam pola RFLP ini diperoleh dari 6 sekuen DNA yang berbeda hasil dari sekuensing. Bila dibandingkan dengan hasil RFLP in silico terhadap berbagai grup fitoplasma yang telah dibuat oleh Wei et al. (2007), maka keenam sekuen DNA tersebut mempunyai nilai koefisiensi kesamaan yang tinggi dengan grup 16SrIIA (peanut witches broom phytoplasma) yakni berkisar antara 0,84-0,98 (Tabel 1). Kelompok witches broom phytoplasma yang berasosiasi dengan penyakit layu kelapa ini baru pertama kali ditemukan di dunia. Umumnya gejala penyakit tanaman yang disebabkan oleh kelompok witches broom phytoplasma meliputi daun yang menguning, virescence, memendek dan berbentuk seperti sapu (witches'broom), kerdil dan bahkan kematian tanaman (Dickinson et al., 2013).

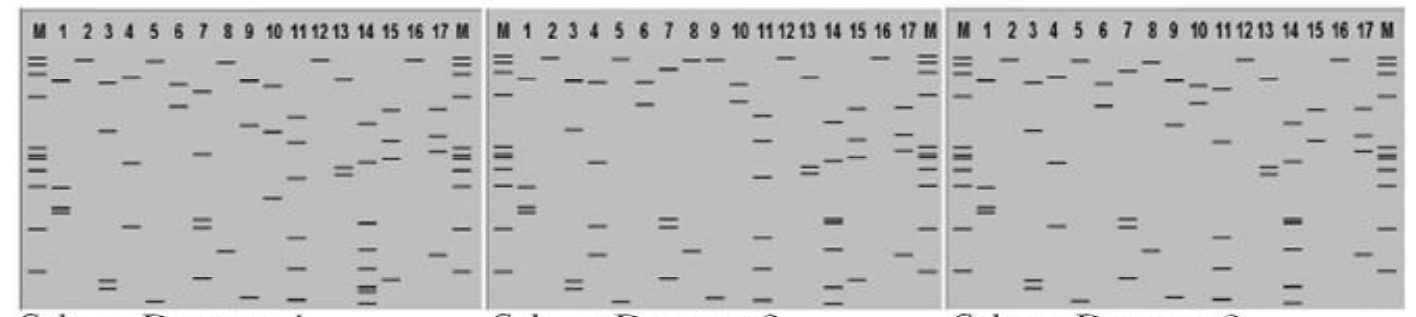

Sekuen Derawan 1

Sekuen Derawan 2

Sekuen Derawan 3

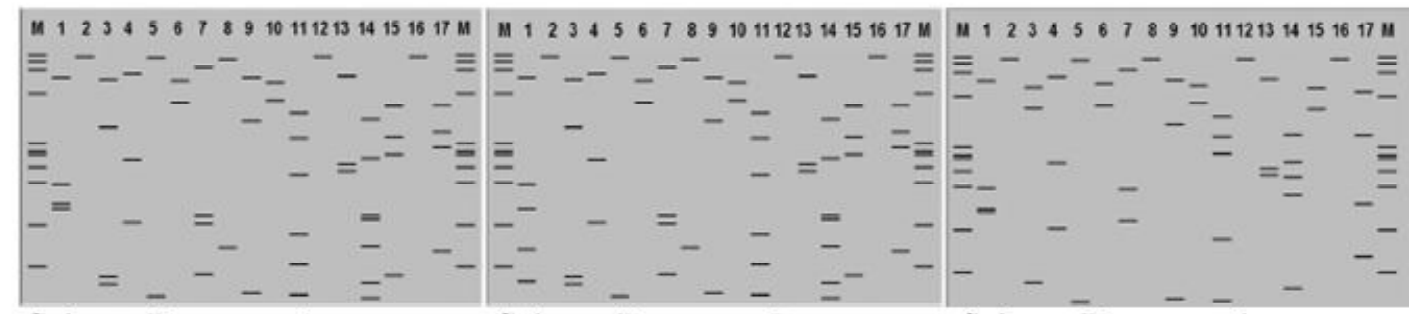

Sekuen Derawan 4

Sekuen Derawan 5

Sekuen Derawan 6

Gambar 2. Ploting hasil analisis RFLP in silico menggunakan 17 enzim restriksi (1-17, berturut-turut AluI, BamHI, BfaI, BstUI, DraI, EcoRI, HaeIII, HhaI, HinfI, HpaI, HpaII, KpnI, Sau3AI, MseI, RsaI, SspI, dan TaqI) terhadap 6 sekuen DNA yang berbeda dari Pulau Derawan pada 3\% gel agarose. M, marker jX174DNA-HaeIII digestion. 
Tabel 1. Koefisien kesamaan yang diperoleh dari analisis pola RFLP in silico gen 16S rRNA dari 6 sekuen DNA asal Pulau Derawan

\begin{tabular}{lccccccccccc}
\hline \multicolumn{1}{c}{$\begin{array}{c}\text { Sekuen } \\
\text { fitoplasma }\end{array}$} & 1 & 2 & 3 & 4 & 5 & 6 & $\mathrm{kw}$ & $\mathrm{p}$ & $\mathrm{s}$ & $\mathrm{IIA}$ & XIA \\
\hline Derawan 1 & 1,00 & & & & & & & & & & \\
Derawan 2 & 0,88 & 1,00 & & & & & & & & & \\
Derawan 3 & 0,88 & 0,86 & 1,00 & & & & & & & & \\
Derawan 4 & 0,92 & 0,94 & 0,98 & 1,00 & & & & & & & \\
Derawan 5 & 0,93 & 0,92 & 0,93 & 0,98 & 1,00 & & & & & & \\
Derawan 6 & 0,74 & 0,72 & 0,79 & 0,75 & 0,76 & 1,00 & & & & & \\
Kalimantan wilt & 0,76 & 0,81 & 0,76 & 0,75 & 0,77 & 0,95 & 1,00 & & & & \\
Peanut & 0,92 & 0,90 & 0,97 & 0,99 & 0,97 & 0,74 & 0,75 & 1,00 & & & \\
Soybean & 0,92 & 0,90 & 0,97 & 0,99 & 0,97 & 0,74 & 0,75 & 1,00 & 1,00 & & \\
16SrIIA & 0,95 & 0,95 & 0,98 & 0,98 & 0,96 & 0,84 & 0,84 & 0,99 & 0,99 & 1,00 & \\
16SrXIA & 0,71 & 0,70 & 0,72 & 0,73 & 0,73 & 0,74 & 0,74 & 0,68 & 0,68 & 0,61 & 1,00 \\
\hline
\end{tabular}

No 1 - 6: Sekuen Derawan 1 - 6 dari kelapa Pulau Derawan, kw: sekuen kalimantan wilt dari kelapa Sampit, p: sekuen dari kacang tanah Bogor, s: sekuen dari kedelai Bogor, 16SrIIA - 16SrXIA (Wei et al., 2007). Koefisien kesamaannya $(\mathrm{F})$ dihitung untuk masing-masing pasangan sekuen DNA fitoplasma berdasarkan rumus $\mathrm{F}=(\mathrm{N}-\mathrm{x}$ -+ N-y-)/2N-xy-, dengan $\mathrm{x}$ dan y merupakan dua strain fitoplasma yang berbeda, N-x -dan N-y- adalah total jumlah fragmen DNA yang dihasilkan dari pemotongan menggunakan 17 enzim restriksi, berturut-turut dari strain fitoplasma $\mathrm{x}$ dan $\mathrm{y}$, serta $\mathrm{N}$-xy- ialah jumlah fragmen DNA dari kedua strain fitoplasma.

\section{SIMPULAN}

Deteksi fitoplasma dengan nPCR menggunakan primer R16F2n/R16R2 menghasilkan fragmen DNA berukuran sekitar $1,25 \mathrm{~kb}$ yang diperoleh dari sampel tanaman kelapa bergejala layu berat, ringan, maupun yang belum bergejala. Analisis filogenetik dan RFLP in silico terhadap sekuen DNA dari Pulau Derawan menggolongkan fitoplasma yang berasosiasi dengan penyakit layu kelapa memiliki hubungan kekerabatan yang tinggi dengan kelompok witches broom phytoplasma (grup 16SrII).

\section{SANCAWANA}

Kami mengucapkan terima kasih kepada Direktur Pusat Penelitian Kelapa Sawit Medan atas dana penelitian, Kelapa Pusat Penelitian Biologi LIPI Cibinong atas kesempatan magang dan pelaksanaan sebagian kegiatan penelitian, dan Prof. Naotake Ogasawara yang telah memberikan segala fasilitas penelitian di Laboratorium Genomic of Bacterial Cell Function, Nara Institute of Science and Technology (NAIST) Jepang melalui program JSPS (The Japan Society for Promoting Sciences).

\section{DAFTAR PUSTAKA}

Anonim. 2007. Prospek dan Arah Pengembangan Agribisnis Kelapa. Ed ke-2. Jakarta: Departemen Pertanian.

Bai XD, Zhang JH, Ewing A, Miller SA, Radek AJ, Shevchenko DV, Tsukerman K, Walunas T, Lapidus A, Campbell JW, \& Hogenhout S A. 2006. Living with genome instability, the adaptation of phytoplasmas to diverse environments of their insect and plant hosts. J. Bacteriol. 188(10): 36823696.

Deng S \& Hiruki C. 1991. Amplification of 16S rRNA genes from culturable and non culturable mollicutes. J. Microbiol. Methods 14(1): 53-61.

Dickinson M, Tuffen M, \& Hodgetts J. 2013. The phytoplasma: an introduction. In: Dickinson M \& Hodgetts J (Eds.) Phytoplasma Methods and Protocols. pp. 1-14. Humana Press, New York.

Gundersen DE \& Lee IM. 1996. Ultrasensitive detection of phytoplasmas by nested PCR assays using two universal primer pairs. Phytopathol. Mediterr. 35(3): 144-151. 
Harrison NA, Myrie W, Jones P, Carpio ML, Castilo M, Doyle MM, \& Oropeza C. 2002. 16S rRNA interoperon sequence heterogeneity distinguishes strain populations of palm lethal yellowing phytoplasma in the Carribean region. Ann. Appl. Biol. 141(2): 183-193.

Leon R, Santamaria JM, Alpizar L, Escamilla JA, \& Oropeza C. 1996. Physiological and biochemical changes in shoots of coconut palms affected by lethal yellowing. New Phytol. 134(2): 227-234.

Musetti R. 2010. Biochemical changes in plant infected by phytoplasma. In: Weintraub PG \& Jones P (Eds.). Phytoplasmas: Genomes, Plant Hosts and Vectors. pp. 132-146. CAB International, Wallingford.

Myrie WA, Paulraj L, Dollet M, Wray D, \& Been BO. 2006. First report of lethal yellowing disease of coconut palms caused by phytoplasma on Nevis Island. Plant Dis. 90(6): 834.

Nejat N, Sijam K, Abdullah SNA, Vadamalai G, \& Dickinson M. 2009. Molecular characterization of a phytoplasma associated with coconut yellow decline (CYD) in Malaysia. Am. J. Appl. Sci. 6(7): 1331-1340.

Oropeza C, Cordova I, Narvaez M, \& Harrison N. 2002. Palm Trunk Sampling for DNA Extraction and Phytoplasma Detection. University of Florida, Florida.
Sambrook J \& Russel DW. 2001. Molecular Cloning, A Laboratory Manual. Ed ke-3. Cold Sping Harbor Laboratory Press, New York.

Tymon AM, Jones P, \& Harrison NA. 1998. Phylogenetic relationships of coconut phytoplasmas and the development of specific oligonucleotide PCR primers. Ann. Appl. Biol. 132(3): 437-452.

Warokka JS, Jones P, \& Dickson MJ. 2006. Detection of phytoplasma associated with kalimantan wilt disease of coconut by the polymerase chain reaction. J. Littri 12(4): 154-160.

Wei W, Davis RE, Lee IM, \& Zhao Y. 2007. Computersimulated RFLP analysis of 16S rRNA genes, identification of ten new phytoplasma groups. Int. J. Syst. Evol. Microbiol. 57: 1855-1867.

Weintraub PG \& Wilson MR. 2010. Control of phytoplasma disease and vectors. In: Weintraub PG \& Jones P (Eds.). Phytoplasmas: Genomes, Plant Hosts and Vectors. pp. 233-266. CAB International, Wallingford.

Zhang YP, Uyemoto JK, \& Kirkpatrick BC. 1998. A small-scale procedure for extracting nucleic acids from woody plants infected with various phytopathogens for PCR assay. J. Virol. Methods 71(1): 45-50. 